\title{
Association between PDCD1, CTLA4, and MECP2 gene polymorphisms and systemic lupus erythematosus in the Chinese Northern Han
}

\author{
H.R. Dong ${ }^{1 *}$, H.S. Li ${ }^{1 *}$, S.C. Wang ${ }^{1}$, Q.M. Balin ${ }^{1}$ and P.Y. Chang ${ }^{2}$ \\ ${ }^{1}$ Clinical Laboratory Department, First Hospital of Hohhot in Inner Mongolia, \\ Hohhot, China \\ 2Department of Nuclear Medicine, Inner Mongolia Medical University Affiliated Hospital, \\ Hohhot, China \\ *These authors contributed equally to this study. \\ Corresponding author: P.Y. Chang \\ E-mail: changpeiye@126.com \\ Genet. Mol. Res. 14 (4): 17567-17573 (2015) \\ Received April 22, 2015 \\ Accepted August 13, 2015 \\ Published December 21, 2015 \\ DOI http://dx.doi.org/10.4238/2015.December.21.29
}

\begin{abstract}
Systemic lupus erythematosus (SLE) is an autoimmune disease that results in chronic inflammation of different organ systems. Several susceptibility loci for SLE have been suggested in different populations, but the nature of the susceptibility genes has yet to be determined. The programmed cell death 1 gene (PDCD1), the cytotoxic T-lymphocyte-associated protein 4 (CTLA4) gene, and the methyl-CpGbinding protein 2 gene (MECP2) are considered to be the candidate genes associated with SLE. We analyzed the role of PDCD1, CTLA4, and MECP2 gene polymorphisms in Han patients suffering from SLE. Using a casecontrol study, 263SLE patients and 263 healthy controls were collected from Chinese Northern Han people. Genomic DNA was prepared from peripheral blood leukocytes and the genotyping was performed using a polymerase chain reaction/ligase detection reaction assay. A statistically
\end{abstract}


significant difference was observed in the rs2239464 and rs2075596 polymorphisms of MECP2 between SLE subjects and controls. The GG genotype in rs2239464 and the GG genotype in rs2075596 might protect against SLE. In contrast, no such association was found in the CTLA4 or $P D C D 1$ polymorphisms. The rs2239464 and rs2075596 polymorphisms of MECP2 might play a significant role in the development of SLE in the Northern Han of China.

Key words: Systemic lupus erythematosus; PDCD1; CTLA4; MECP2; Single nucleotide polymorphism

\section{INTRODUCTION}

Systemic lupus erythematosus (SLE) is a complex autoimmune disease that is characterized by autoantibody production (Walunas et al., 1996). The disease occurs primarily in women of childbearing age (Utz, 2004). The underlying pathogenic mechanism of SLE remains unclear; the disease is complex and involves multiple genetic and environmental factors (Kyogoku and Tsuchiya, 2007). The genetic component of SLE exerts a strong influence, with familial aggregation studies showing a sibling risk ratio of 20-29 (Hochberg, 1987; Alarcón-Segovia et al., 2005). Recently, several novel susceptibility genes of SLE have been identified. Programmed cell death $1(P D C D 1)$, cytotoxic T-lymphocyte-associated protein 4 (CTLA4), and methyl-CpG-binding protein 2 (MECP2) genes, among others, have been associated with susceptibility to SLE in several studies. However, more conclusive evidence is required to establish the role of these genes in SLE pathogenesis (Rhodes and Vyse, 2007; Rhodes and Vyse, 2008).

There are many reasons why true susceptibility genes may remain unreplicated in genome-wide association studies, and therefore replication studies of suggested genes continue to be relevant. Our aim was to investigate whether certain susceptibility genes implicated in the recent SLE literature can be replicated in the Chinese Northern Han population.

\section{MATERIAL AND METHODS}

\section{Patients and controls}

The case-control study included 263 SLE patients and 263 age- and sex-matched healthy blood donors (both of Han origin). SLE patients were recruited from the department of Rheumatology at the Affiliated Hospital of Peking Union Medical College, the First Hospital of Hohhot in Inner Mongolia, and the Inner Mongolia Medical University Affiliated Hospital between 2010 and 2012. All patients met the American College of Rheumatology Classification (ACRC) criteria for the diagnosis of SLE (Tan et al., 1982). Unaffected, biologically unrelated family members (spouses and common-law spouses) were asked to participate as control individuals, and an existing collection of unrelated Han individuals was also used. All subjects gave written informed consent for participation in the genetic studies on SLE, and the study protocols were reviewed and approved by local ethical committees. 


\section{DNA extraction and genotyping}

Genomic DNA was extracted from the leukocytes in peripheral blood samples using a commercial blood DNA extraction kit (TIANamp Blood DNA kit; TIANGEN BIOTECH, Beijing, China), and was stored at $-20^{\circ} \mathrm{C}$. All genotyping was performed using a polymerase chain reaction $(\mathrm{PCR}) /$ ligase detection reaction assay.

The target DNA sequences were amplified using a multiplex PCR method. PCRs for each subject were carried out in a final volume of $20 \mu \mathrm{L}$ containing $1 \mathrm{X}$ PCR buffer, $3.0 \mathrm{mM} \mathrm{MgCl}, 2.0$ $\mathrm{mM}$ deoxynucleotide triphosphate, $2 \mu \mathrm{L}$ primers, $0.2 \mu \mathrm{L}$ Qiagen HotStarTaq Polymerase (QIAGEN, Shenzhen, China), $4 \mu \mathrm{L} 1 \mathrm{X}$ Q-solution, and $50 \mathrm{ng}$ genomic DNA. Thermal cycling was performed using a GeneAmp PCR 9600 system (PerkinElmer, Norwalk, Connecticut, USA) with an initial denaturation of $15 \mathrm{~min}$ at $95^{\circ} \mathrm{C}$, followed by 35 cycles of denaturation at $94^{\circ} \mathrm{C}$ for $30 \mathrm{~s}$, annealing at $56^{\circ} \mathrm{C}$ for $1 \mathrm{~min}$, extension at $72^{\circ} \mathrm{C}$ for $1 \mathrm{~min}$, and a final extension at $72^{\circ} \mathrm{C}$ for $7 \mathrm{~min}$.

The ligation reaction for each subject was carried out in a final volume of $10 \mu \mathrm{L}$ containing 1X NEB Taq DNA ligase buffer, 2 pmol each probe mix, $0.05 \mu \mathrm{L}$ Taq DNA ligase (BIOWING, Jiangsu, China), and $4 \mu \mathrm{L}$ multi-PCR product. A total of 35 cycles for ligase detection reaction were performed at $95^{\circ} \mathrm{C}$ for $2 \mathrm{~min}, 94^{\circ} \mathrm{C}$ for $30 \mathrm{~s}$, and $50^{\circ} \mathrm{C}$ for $2 \mathrm{~min}$. The fluorescent products of the ligase detection reaction were differentiated using a PRISM 3730 DNA analyzer (ABI).

\section{Statistical analysis}

The Statistical Program for Social Sciences (SPSS version 17.0) was used to carry out statistical analysis. Hardy-Weinberg equilibrium was determined in each group using the chi-square test. Allele and genotype frequencies between groups were completed using SHEsis software.

\section{RESULTS}

\section{Clinical characteristics of SLE and control subjects}

The characteristics of the SLE and control subjects are shown in Table 1. Significant differences in $\mathrm{C} 3$, IgA, IgM, white blood cell count (WBC), red blood cell count (RBC), hemoglobin (HGB), lymphocyte count (LYM), neutrophil count (NEUT), alanine aminotransferase (ALT), aspartate aminotransferase (AST), erythrocyte sedimentation rate (ESR), C-reactive protein (CRP), and gamma-glutamyl transpeptidase (GGT) were observed between the SLE patients and the controls (P $<0.05$ ). There were no significant differences in $\mathrm{C} 4$, IgG, and gender between the groups.

\section{Single-locus association study of genes and SLE}

Genotype analysis of all the investigated polymorphisms revealed no significant deviation from Hardy-Weinberg equilibrium in either group $(P>0.05)$. The genotype and allele frequency distributions are shown in Table 2. There were significant differences in the distribution of genotypes frequency in the rs2239464 and rs2075596 polymorphisms of MECP2 between the SLE subjects and the controls. The GG genotype in rs2239464 and the GG genotype in rs2075596 might protect against SLE. There were no significant differences in the distribution of genotypes and allele frequencies of $318 \mathrm{C} / \mathrm{T}$ and 1722 T/C in CTLA4, and no significant differences were found in the distribution of genotypes and allele frequencies in the rs2227981, rs2227982, and rs11568821 polymorphisms of PDCD1. 
Table 1. Characteristics of systemic lupus erythrematosus (SLE) patients and controls.

\begin{tabular}{lccc}
\hline & SLE & Controls & $P$ \\
\hline Male/female & $31 / 263$ & $31 / 263$ & 0.87 \\
Age (years) & $39.40 \pm 14.75$ & $38.18 \pm 13.07$ & 0.29 \\
C3 $(\mathrm{g} / \mathrm{L})$ & $0.94 \pm 0.26$ & $1.49 \pm 0.25$ & $0.00^{* *}$ \\
C4 $(\mathrm{g} / \mathrm{L})$ & $0.27 \pm 0.88$ & $0.27 \pm 0.07$ & 0.99 \\
$\operatorname{lgA}(\mathrm{g} / \mathrm{L})$ & $2.82 \pm 1.29$ & $4.79 \pm 3.35$ & $0.00^{* *}$ \\
$\operatorname{lgG}(\mathrm{g} / \mathrm{L})$ & $13.68 \pm 3.83$ & $13.39 \pm 3.97$ & 0.37 \\
$\operatorname{lgM}(\mathrm{g} / \mathrm{L})$ & $1.13 \pm 0.74$ & $5.75 \pm 1.34$ & $0.00^{* *}$ \\
WBC $\left(10^{9} / \mathrm{L}\right)$ & $7.13 \pm 3.43$ & $5.20 \pm 0.78$ & $0.00^{* *}$ \\
RBC $\left(10^{12} / \mathrm{L}\right)$ & $4.45 \pm 0.72$ & $157.36 \pm 11.67$ & $0.00^{* *}$ \\
HGB $(\mathrm{g} / \mathrm{L})$ & $133.93 \pm 19.65$ & $37.38 \pm 5.81$ & $0.00^{* *}$ \\
LYM $\left(10^{9} / \mathrm{L}\right)$ & $19.76 \pm 13.95$ & $54.84 \pm 7.08$ & $0.00^{* *}$ \\
NEUT $\left(10^{\prime} / \mathrm{L}\right)$ & $48.98 \pm 28.72$ & $25.67 \pm 7.79$ & $0.00^{* *}$ \\
ALT $(\mathrm{U} / \mathrm{L})$ & $35.09 \pm 36.87$ & $28.27 \pm 8.09$ & $0.00^{* *}$ \\
AST $(\mathrm{U} / \mathrm{L})$ & $33.75 \pm 34.22$ & $25.91 \pm 7.69$ & $0.01^{*}$ \\
GGT $(\mathrm{U} / \mathrm{L})$ & $57.33 \pm 119.12$ & $11.59 \pm 5.87$ & $0.00^{* *}$ \\
ESR $(\mathrm{mM})$ & $20.85 \pm 18.24$ & $1.77 \pm 0.82$ & $0.00^{* *}$ \\
CRP $(\mathrm{mL} / \mathrm{h})$ & $5.85 \pm 6.26$ & $0.00^{* *}$ \\
\hline
\end{tabular}

WBC = white blood cell count; RBC = red blood cell count; HGB = hemoglobin; LYM = lymphocyte count; NEUT = neutrophil count; $A L T=$ alanine aminotransferase; $A S T$ = aspartate aminotransferase; $E S R=$ erythrocyte sedimentation rate; $\mathrm{CRP}=\mathrm{C}$-reactive protein; $\mathrm{GGT}=$ gamma-glutamyl transpeptidase Data are reported as mean \pm standard deviation. ${ }^{*} \mathrm{P}<0.05,{ }^{* *} \mathrm{P}<0.01$.

Table 2. Frequency distribution of CTLA4, PDCD1, and MECP2 genotypes and alleles.

\begin{tabular}{|c|c|c|c|c|c|}
\hline Gene polymorphism & Genotype/allele & SLE, N (\%) & Controls, N (\%) & $x^{2}$ & $\mathrm{P}$ \\
\hline \multirow{5}{*}{$318 \mathrm{C} / \mathrm{T}$} & $\mathrm{CC}$ & $209(0.721)$ & $224(0.775)$ & 4.47 & 0.11 \\
\hline & $\mathrm{CT}$ & $79(0.272)$ & $60(0.208)$ & & \\
\hline & $\mathrm{TT}$ & $2(0.007)$ & $5(0.017)$ & & \\
\hline & $\mathrm{C}$ & $497(0.857)$ & $510(0.879)$ & 1.27 & 0.26 \\
\hline & $\mathrm{T}$ & $83(0.143)$ & $70(0.121)$ & & \\
\hline \multirow[t]{5}{*}{$1722 \mathrm{~T} / \mathrm{C}$} & $\mathrm{CC}$ & $33(0.114)$ & $28(0.097)$ & 0.46 & 0.79 \\
\hline & $\mathrm{CT}$ & $121(0.417)$ & $123(0.424)$ & & \\
\hline & $\mathrm{TT}$ & $136(0.469)$ & $139(0.479)$ & & \\
\hline & C & $187(0.322)$ & $179(0.309)$ & 0.26 & 0.61 \\
\hline & $\mathrm{T}$ & $393(0.678)$ & $401(0.691)$ & & \\
\hline \multirow[t]{4}{*}{ rs11568821 } & AG & $3(0.010)$ & $2(0.007)$ & 0.20 & 0.65 \\
\hline & GG & $287(0.990)$ & $288(0.993)$ & & \\
\hline & A & $3(0.005)$ & $2(0.003)$ & 0.20 & 0.65 \\
\hline & G & $577(0.995)$ & $578(0.997)$ & & \\
\hline \multirow[t]{5}{*}{ rs2227981 } & $\mathrm{CC}$ & $150(0.517)$ & $165(0.569)$ & 2.76 & 0.25 \\
\hline & $\mathrm{CT}$ & $114(0.393)$ & $108(0.372)$ & & \\
\hline & TT & $26(0.090)$ & $17(0.059)$ & & \\
\hline & C & $414(0.714)$ & $438(0.755)$ & 2.55 & 0.11 \\
\hline & $\mathrm{T}$ & $166(0.286)$ & $142(0.245)$ & & \\
\hline \multirow[t]{5}{*}{ rs2227982 } & $\mathrm{CC}$ & $79(0.272)$ & $70(0.241)$ & 1.22 & 0.54 \\
\hline & $\mathrm{CT}$ & $142(0.490)$ & $141(0.486)$ & & \\
\hline & $\mathrm{TT}$ & $69(0.238)$ & $79(0.272)$ & & \\
\hline & $\mathrm{C}$ & $300(0.517)$ & $281(0.484)$ & 1.24 & 0.26 \\
\hline & $\mathrm{T}$ & $280(0.483)$ & $299(0.516)$ & & \\
\hline \multirow[t]{5}{*}{ rs2239464 } & AA & $189(0.652)$ & $201(0.693)$ & 14.77 & 0.00 \\
\hline & $A G$ & $87(0.300)$ & $56(0.193)$ & & \\
\hline & GG & $14(0.048)$ & $33(0.114)$ & & \\
\hline & $A$ & $465(0.802)$ & $458(0.790)$ & 0.26 & 0.61 \\
\hline & G & $115(0.198)$ & $122(0.210)$ & & \\
\hline \multirow[t]{5}{*}{ rs2075596 } & AA & $183(0.631)$ & $183(0.631)$ & 1.75 & 0.00 \\
\hline & $A G$ & $89(0.307)$ & $61(0.210)$ & & \\
\hline & GG & $18(0.062)$ & $46(0.159)$ & & \\
\hline & $A$ & $455(0.784)$ & $427(0.736)$ & 3.71 & 0.054 \\
\hline & G & $125(0.216)$ & $153(0.264)$ & & \\
\hline
\end{tabular}

SLE $=$ systemic lupus erythrematosus ${ }^{*} \mathrm{P}<0.05$, ${ }^{* *} \mathrm{P}<0.01$ 


\section{DISCUSSION}

Cytotoxic T lymphocyte-associated antigen 4 (CTLA4) plays a key role in the regulation of T-cell stimulation and inhibits T-cell activation (Chai et al., 2012). Reduced expression or dysfunction of CTLA4 contributes to the pathogenesis of autoimmune diseases. Consequently, CTLA4 gene polymorphisms are associated with several autoimmune diseases, such as type I diabetes (Ahmadi et al., 2013), rheumatoid arthritis (Davis et al., 2014), and SLE (Kristiansen, 2000). Furthermore, numerous studies have investigated the association between $318 \mathrm{C} / \mathrm{T}$ and $1722 \mathrm{~T} / \mathrm{C}$ polymorphisms of the CTLA4 gene and SLE. However, the results are controversial (Parks et al., 2004; Takeuchi et al., 2007; Chua et al., 2010). Shojaa et al. (2014a) conducted a meta-analysis on 1422 SLE cases and 1417 controls from nine published studies. The results suggested that the TC and TT genotypes of the 1722T/C polymorphism are related to an increased risk of SLE in the overall population and especially in Asians. Shojaa et al. (2014b) found that the 318C/T polymorphism of CTLA4 might play a significant role in the development of SLE in the Iranian population. However, in our study we did not find a relationship between the $318 \mathrm{C} / \mathrm{T}$ and $1722 \mathrm{~T} / \mathrm{C}$ polymorphisms of CTLA4 and SLE in the Han population.

PDCD1 is an immunoreceptor that suppresses the autoimmune response and maintains selftolerance. Reduced expression or dysfunction of PDCD1 might result in the breakdown of peripheral tolerance and the onset of autoimmune diseases, and mice lacking PDCD1 develop an SLE-like disease (Ferreiros-Vidal et al., 2004; Johansson et al., 2005). Many polymorphisms have been found in the PDCD1 gene, which has the SLE-susceptible chromosomal locus 2q37 (Lindqvist et al., 2000). Moreover, numerous investigations have indicated that $P D C D 1$ gene polymorphisms contribute to the development of SLE (Ferreiros-Vidal et al., 2004). Prokunina et al (2002) found that a regulatory single-nucleotide polymorphism (SNP) PD1.3G/A located in the programmed cell death 1 (PDCD1) gene is involved in susceptibility to SLE in Swedish, European American, and Mexican cases. Metaanalysis has demonstrated a significant association between PD1.3A and SLE among non-Spanish European descendants, while a negative association was observed in a Spanish population (Liu et al., 2009). In this study, we investigated the associations between rs2227981, rs2227982, and rs11568821 polymorphisms of the PDCD1 gene and SLE, but did not find any.

MECP2, with the chromosomal locus $\mathrm{Xq} 28$, encodes a 486-amino acid protein that binds methylated DNA and is involved in the transcriptional regulation of methylation-sensitive genes (Miltenberger-Miltenyi and Laccone, 2003). DNA methylation-sensitive genes are overexpressed in SLE (Jones et al., 1998) and MECP2 is critical in the transcriptional suppression of methylationsensitive genes (Koelsch et al., 2013), which makes MECP2 an attractive candidate gene for SLE. (Sawalha et al., 2008) confirmed the association between SLE and all eight SNPs within the MECP2 gene including rs2075596, which has previously been reported in European SLE patients and controls in a Korean population. A meta-analysis of the association between the rs2075596 and rs2239464 polymorphisms of MECP2 and SLP showed that the SNPs increased the risk of developing SLE (Liu et al., 2013). Our results also revealed an association between the rs2075596 and rs2239464 SNPs of MECP2 and SLE in Chinese Northern Han.

There are many other factors such as age, gender, age at onset, disease severity, family history, and smoking habits that may explain why a single polymorphism acts differently in dissimilar ethnic groups.

In conclusion, using a candidate gene approach and a case-control genetic association study, we found that the rs2239464 and rs2075596 polymorphisms of MECP2 might play a significant role in the development of SLE in Chinese Northern Han. To confirm the associations 
between PDCD1, CTLA4, and MECP2 gene variants and SLE, large-scale studies in other populations are urgently required.

\section{Conflicts of interest}

The authors declare no conflict of interest.

\section{ACKNOWLEDGMENTS}

Research supported by the Inner Mongolia Hohhot Technology Bureau (\#2012-Social Development-2-2).

\section{REFERENCES}

Ahmadi S, Rostamzadeh J, Khosravi D, Shariati P, et al. (2013). Association of CTLA-4 gene 49A/G polymorphism with the incidence of type 1 diabetes mellitus in the Iranian Kurdish population. Pak. J. Biol. Sci. 16: 1929-1935.

Alarcón-Segovia D, Alarcón-Riquelme ME, Cardiel MH, Caeiro F, et al. (2005). Familial aggregation of systemic lupus erythematosus, rheumatoid arthritis, and other autoimmune diseases in 1,177 lupus patients from the GLADEL cohort. Arthritis Rheum. 52: 1138-1147.

Chai HC, Phipps ME and Chua KH (2012). Genetic risk factors of systemic lupus erythematosus in the Malaysian population: A minireview. Clin. Dev. Immunol. 2012: 963730.

Chua KH, Puah SM, Chew CH, Tan SY, et al. (2010). Study of the CTLA-4 gene polymorphisms in systemic lupus erythematosus (SLE) samples from Malaysia. Ann. Hum. Biol. 37: 274-280.

Davis LA, Whitfield E, Cannon GW, Wolff RK, et al. (2014). Association of rheumatoid arthritis susceptibility gene with lipid profiles in patients with rheumatoid arthritis. Rheumatology (Oxford) 53: 1014-1021.

Ferreiros-Vidal I, Gomez-Reino JJ, Barros F, Carracedo A, et al. (2004). Association of PDCD1 with susceptibility to systemic lupus erythematosus: evidence of population-specific effects. Arthritis Rheum. 50: 2590-2597.

Hochberg MC (1987). The application of genetic epidemiology to systemic lupus erythematosus. J. Rheumatol. 14: 867-869.

Johansson M, Arlestig L, Möller B and Rantapää-Dahlqvist S (2005). Association of a PDCD1 polymorphism with renal manifestations in systemic lupus erythematosus. Arthritis Rheum. 52: 1665-1669.

Jones PL, Veenstra GJ, Wade PA, Vermaak D, et al. (1998). Methylated DNA and MeCP2 recruit histone deacetylase to repress transcription. Nat. Genet. 19: 187-191.

Koelsch KA, Webb R, Jeffries M, Dozmorov MG, et al. (2013). Functional characterization of the MECP2/IRAK1 lupus risk haplotype in human T cells and a human MECP2 transgenic mouse. J. Autoimmun. 41: 168-174.

Kristiansen OP, Larsen ZM and Pociot F (2000). CTLA-4 in autoimmune diseases-a general susceptibility gene to autoimmunity? Genes Immun. 1: 170-184.

Kyogoku C and Tsuchiya N (2007). A compass that points to lupus: genetic studies on type I interferon pathway. Genes Immun. 8: $445-455$.

Lindqvist AK, Steinsson K, Johanneson B, Kristjánsdóttir H, et al. (2000). A susceptibility locus for human systemic lupus erythematosus (hSLE1) on chromosome 2q. J. Autoimmun. 14: 169-178.

Liu JL, Zhang FY, Liang YH, Xiao FL, et al. (2009). Association between the PD1.3A/G polymorphism of the PDCD1 gene and systemic lupus erythematosus in European populations: a meta-analysis. J. Eur. Acad. Dermatol. Venereol. 23: 425-432.

Liu K, Zhang L, Chen J, Hu Z, et al. (2013). Association of MeCP2 (rs2075596, rs2239464) genetic polymorphisms with systemic lupus erythematosus: a meta-analysis. Lupus 22: 908-918.

Miltenberger-Miltenyi G and Laccone F (2003). Mutations and polymorphisms in the human methyl CpG-binding protein MECP2. Hum. Mutat. 22: 107-115.

Parks CG, Hudson LL, Cooper GS, Dooley MA, et al. (2004). CTLA-4 gene polymorphisms and systemic lupus erythematosus in a population-based study of whites and African-Americans in the southeastern United States. Lupus 13: 784-791.

Prokunina L, Castillejo-López C, Oberg F, Gunnarsson I, et al. (2002). A regulatory polymorphism in PDCD1 is associated with susceptibility to systemic lupus erythematosus in humans. Nat. Genet. 32: 666-669.

Rhodes B and Vyse TJ (2007). General aspects of the genetics of SLE. Autoimmunity 40: 550-559.

Rhodes B and Vyse TJ (2008). The genetics of SLE: an update in the light of genome-wide association studies. Rheumatology (Oxford) 47: 1603-1611. 
Sawalha AH, Webb R, Han S, Kelly JA, et al. (2008). Common variants within MECP2 confer risk of systemic lupus erythematosus. PLoS One 3: e1727.

Shojaa M, Aghaie M, Qorbani M, Khashayar P, et al. (2014a). Association of the CTLA-4 1722TC polymorphism and systemic lupus erythematosus: a systematic review and meta analysis. Med. J. Islam. Repub. Iran. 28: 132.

Shojaa M, Aghaie M, Amoli M, Javid N, et al. (2014b). Association between 318C/T polymorphism of the CTLA-4 gene and systemic lupus erythematosus in Iranian patients. Int. J. Rheum. Dis. doi: 10.1111/1756-185X.12275. [Epub ahead of print].

Takeuchi F, Nakaue N, Kawasugi K, Mori M, et al. (2007). The CTLA-4 -1661A/G and -1772T/C dimorphisms in Japanese patients with systemic sclerosis. Rheumatol. Int. 27: 785-787.

Tan EM, Cohen AS, Fries JF, Masi AT, et al. (1982). The 1982 revised criteria for the classification of systemic lupus erythematosus. Arthritis Rheum. 25: 1271-1217.

Utz PJ (2004). Multiplexed assays for identification of biomarkers and surrogate markers in systemic lupus erythematosus. Lupus 13: 304-311.

Walunas TL, Bakker CY and Bluestone JA (1996). CTLA-4 ligation blocks CD28-dependent T cell activation. J. Exp. Med. 183: 2541-2550. 